\title{
Stress level of nursing students due to online learning during the covid-19 pandemic
}

\author{
Sintiya Halisya Pebriani' ${ }^{1}$, Abdul Syafei ${ }^{2}$, Mardiah Mardiah ${ }^{1}$ \\ 1 Program Studi DIII Keperawatan STIK Siti Khadijah Palembang, Indonesia \\ 2 Program Studi Ilmu Keperawatan STIK Siti Khadijah Palembang, Indonesia
}

\begin{tabular}{|c|c|}
\hline Article Info & Abstract \\
\hline $\begin{array}{l}\text { Article History: } \\
\text { Submitted: Dec } 26^{\text {th }}, 2020 \\
\text { Accepted: Oct } 28^{\text {th }}, 2021 \\
\text { Published: Nov } 25^{\text {th }}, 2021 \\
\text { Keywords: } \\
\text { Stress; Online Learning; } \\
\text { Covid-19 }\end{array}$ & $\begin{array}{l}\text { Changes in learning methods to online learning due to the Covid-19 } \\
\text { pandemic have an impact on the psychology of students. Constraints related } \\
\text { to the implementation of online learning cause students to experience stress. } \\
\text { This study aims to investigate the effect of online learning on stress levels in } \\
\text { nursing students at STIK Siti Khadijah Palembang. The research was } \\
\text { descriptive correlation design with cross-sectional approach, the total } \\
\text { sample was } 230 \text { students with total sampling technique. Data were collected } \\
\text { through online-based questionnaires (google form), namely the online } \\
\text { learning constraints questionnaire and the Perceived Stress Scale (PSS-10). } \\
\text { Data analysis using the chi-square test. The results showed that most of the } \\
\text { students (50.9\%) experienced enough problems in online learning and } \\
\text { almost all students ( } 90.9 \% \text { ) experienced moderate stress, statistical tests } \\
\text { showed that there was an effect (p = 0.007) of online learning with stress } \\
\text { levels on nursing students. The obstacles that students feel during online } \\
\text { learning such as starting to feel bored, weak internet network, limited } \\
\text { internet quota, difficulty concentrating and understanding the material, } \\
\text { many lecture assignments, lack of understanding of electronic media are } \\
\text { stress triggers for students, so it can be concluded that there is an effect of } \\
\text { learning online during the Covid-19 pandemic with stress levels in nursing } \\
\text { students. }\end{array}$ \\
\hline
\end{tabular}

\section{PENDAHULUAN}

Saat ini, pandemi Covid-19 menjadi salah satu masalah kesehatan yang meresahkan seluruh dunia. WHO sudah menetapkan bahwa covid-19 atau yang lebih dikenal dengan Coronavirus Disease merupakan Public Health Emergency of International Concern (PHEIC) atau Kedaruratan Kesehatan Masyarakat Yang Meresahkan Dunia (KKMMD) yang sekarang virusnya sudah menyebar ke berbagai negara[1].
Untuk mememutus rantai penyebaran dan menurunkan angka kematian Covid-19 maka diperlukan tindakan pencegahan dan pengendalian penyakit ini, salah satunya yaitu dengan melakukan pembantasan interkasi fisik dan pembatasan sosial (Physical contact/social distancing). Tindakan ini berdampak pada penutupan instansi pendidikan. Surat Edaran Mendikbud Nomor 36962/MPK.A/HK/2020 menyatakan agar seluruh kegiatan belajar mengajar baik di

Corresponding author:

Sintiya Halisya Pebriani

sintiyahp88@gmail.com

Media Keperawatan Indonesia, Vol 4 No 4, November 2021

e-ISSN: 2615-1669

ISSN: 2722-2802

DOI: $10.26714 / \mathrm{mki} .4 .4 .2021 .285-290$ 
sekolah maupun kampus perguruan tinggi menggunakan metode daring atau online sebagai upaya pencegahan terhadap perkembangan dan penyebaran Coronavirus disease (Covid-19).

Perubahan metode pembelajaran ini memberikan dampak kepada mahasiswa sebagai salah satu individu dengan jumlahnya paling banyak di institusi pendidikan, dimana proses pembelajaran yang biasanya dilakukan dengan tatap muka di ruang kelas ataupun praktikum dilaboratorium/lahan praktek berubah menjadi daring [2]. Pembelajaran secara daring dilaksanakan dengan berbagai metode oleh para pendidik diantaranya melalui aplikasi whatsapp, zoom, google class dan lain sebagainya.

Perubahan metode pembelajaran yang terjadi pada mahasiswa ini tentunya memberikan dampak pada psikologis mahasiswa. Pembelajaran secara online dapat menyebabkan beberapa mahasiswa mengalami stres dan tidak dapat mengikuti pembelajaran dengan baik dan benar [3]. Hal ini sesuai dengan penelitian terdahulu dimana gambaran kondisi psikologis pada 190 mahasiswa dalam proses pembelajaran di masa pandemi Covid-19 yaitu sebanyak 79 mahasiswa mengalami kecemasan ringan, sisanya 23 mahasiswa mengalami stres ringan dan hanya 7 mahasiswa dengan depresi ringan[4]. Mahasiswa yang telah mengikuti perkuliahan jarak jauh $\geq 12$ kali cenderung mengalami stres tingkat rendah dibandingkan dengan mahasiswa yang hanya mengikuti perkuliahan jarak jauh < 12 kali [5].

Hal ini dapat disebabkan oleh berbagai kendala, dimana kendala yang paling sering dialami dalam proses pembelajaran daring meliputi jaringan internet (sinyal), sulit berkomunikasi dan memahami materi, kebutuhan kuota internet, dan kurang memahami penggunaan media elektronik [4]. Hal ini didukung oleh hasil penelitian yang menganalisis faktor penyebab stres pada 1.129 mahasiswa dari berbagai provinsi di Indonesia selama pandemi Covid-19, dimana ditemukan sebanyak 70\% mahasiswa memilih tugas pembelajaran sebagai faktor utama penyebab stres, selebihnya $55,8 \%$ mahasiswa merasa bosan dengan pembelajaran daring, sebanyak $37,4 \%$ mahasiwa mengeluh tidak bisa mengikuti pembelajaran daring karena keterbatasan kuota internet, 35\% mahasiswa merasa sulit mengaplikasikan pembelajaran praktek dilaboratorium karena ketidaktersediaan alat [2].

Kesulitan mengikuti pembelajaran daring juga dikarenakan tidak semua wilayah memiliki jaringan internet yang lancar [6]. Ketika pembelajaran daring diterapkan di institusi pendidikan, sebagian besar mahasiswa pulang ke daerah masingmasing, hal ini membuat mereka mengalami kesulitan sinyal selular. Disamping itu pembelajaran daring juga menyulitkan mahasiwa berkonsentrasi dan memahami materi yang diberikan, dimana mahasiswa menghayal lebih sering pada perkuliahan daring dibandingkan ketika perkuliahan tatap muka[7]. Perkuliahan secara daring membutuhkan usaha untuk memahami materi yang biasanya dilakukan secara lisan menjadi tulisan dan video atau live streaming[8]. Penelitian membuktikan sebagian besar (89\%) mahasiswa menunjukkan kesulitan dalam bekonsentrasi ketika belajar daring dari rumah [9].

Stres merupakan suatu reaksi atau respon psikologis manusia ketika dihadapkan pada sesuatu yang dianggap melampui batas atau sulit untuk dihadapi [10]. Stres adalah pengalaman yang sangat sering dialami oleh mahasiswa yang dapat berdampak pada menurunnya kemampuan akademik, gangguan kesehatan, depresi, dan gangguan tidur [11]. Kondisi stres yang terus berlangsung dan tidak segera ditangani dapat menyebabkan masalah kesehatan yang lebih serius baik itu kesehatan fisik maupun psikis, oleh karena itu perlu diketahui bagaimana dampak pembelajaran 
daring terhadap tingkat stres pada mahasiswa.

\section{METODE}

Desain penelitian yang digunakan adalah deskriptif korelasi dengan pendekatan cross sectional. Populasi dalam penelitian ini seluruh mahasiswa keperawatan STIK Siti Khadijah berjumlah 230 yang terdiri dari mahasiswa program studi ilmu keperawatan dan DIII keperawatan. Pengambilan sampel dengan total sampling dengan kriteria pemilihan sampel yaitu mahasiswa keperawatan yang sedang melaksanakan pembelajaran daring dan bersedia menjadi responden.

Instrumen yang digunakan pada penelitian ini adalah kuesioner berbasis online melalui google form. Kuesioner terdiri dari kuesioner kendala pembelajaran daring dan kuesioner tingkat stres. Kuesioner pembelajaran daring memodifikasi dari penelitian Hasanah et al., (2020) yang menganalsis penyebab stres mahasiswa selama pandemi Covid-19 dan penelitan $\mathrm{Ph}$, Fatkhul Mubin and Basthomi (2020) yang menganalisis gambaran psikologis mahasiswa dalam proses pembelajaran selama pandemi Covid-19. Kuesioner ini terdiri dari 6 pernyataan mengenai proses pembelajaran daring yaitu proses pembelajaran daring/online yang mulai membosankan, tidak dapat mengikuti pembelajaran daring/online karena kuota internet terbatas, tidak dapat mengaplikasikan pembelajaran praktek laboratorium karena ketidaktersedian alat, sulit berkonsentrasi dan memahami materi pembelajaran, tugas perkuliahan yang banyak, dan kurang pahan dalam menggunakan media elektronik. Uji validitas pada kuesioner ini didapatkan $r$ hitung lebih besar dari $r$ tabel sehingga seluruh pernyataan valid dan uji reabilitas didapatkan nilai Cronbach's alpha 0,779 (> 0,060 ) yang artinya kuesioner tersebut memiliki tingkat reabilitas yang tinggi. Kuesioner tingkat stres memakai kuesioner Perceived Stress Scale (PSS-10) oleh Sheldon
Cohen yang telah terstandart dan memiliki tingkat validitas dan reabilitas yang tinggi dengan nilai Cronbach's alpha sebesar 0,80. Kuesioner ini terdiri dari 10 pertanyaan yang mengukur evaluasi seseorang dari situasi stres dalam satu bulan terakhir.

Penelitian dilakukan setelah mendapat etical clearance dari Komisi Etik Penelitian Kesehatan Politeknik Kesehatan Kemenkes Palembang (No.498KEPK/Adm2/XI/2020). Peneliti menjelaskan penelitian dan tujuan penelitian kepada responden, dan selanjutnya responden memberikan persetujuan menjadi responden melalui google form. Data hasil riset di analisis secara univariat dan bivariat. Analisis univariat mendeskripsikan masing-masing variabel dan karakteristik responden yang terdiri dari usia, jenis kelamin dan jenjang pendidikan. Analisis bivariat menggunakan uji chie square dengan derajat kepercayaan $95 \%(\alpha=0,05)$.

\section{HASIL}

Dari hasil penelitian diketahui rerata usia responden adalah 19 tahun dengan usia minimal 17 tahun dan usia maksimal 24 tahun. Mayoritas responden berjenis kelamin perempuan dan mayoritas mahasiswa program studi D3 Keperawatan.

Hasil penelitian menunjukkan bahwa sebagian besar responden memiliki kendala dalam pembelajaran daring kategori sedang yaitu sebanyak 117 (50.9\%) responden, sedangkan yang merasakan kendala dalam pembelejaran daring kategori berat sebanyak 99 (43\%) responden, dan hanya $14(6.1 \%)$ responden yang memiliki kendala dalam pembelajaran daring kategori ringan. Sedangkan pada tingkat stres didapatkan mayoritas responden mengalami stres sedang yaitu sebanyak 209 $(90,9 \%)$ responden, sedangkan yang memiliki tingkat stres ringan sebanyak 15 $(6,5 \%)$ responden dan hanya $6(2,6 \%)$ responden yang memiliki tingkat stres yang berat. 
Hasil uji chi square didapatkan $\rho$ value $=$ 0,007 yang menunjukkan bahwa ada pengaruh kendala dalam pembelajaran daring terhadap tingkat stres mahasiswa keperawatan STIK Siti Khadijah Palembang, dimana mayoritas responden memiliki kendala pembelajaran daring kategori sedang terdapat 102 responden yang mengalami stres sedang, yang sisanya sebanyak 12 responden mengalami stres ringan dan 3 responden dengan stres berat, sedangkan dari 99 responden yang memiliki kendala pembelajaran daring kategori berat terdapat 95 responden yang mengalami stres sedang yang sisanya 15 responden dengan stres ringan dan hanya 6 responden dengan stres berat. Dan dari 14 responden yang memiliki kendala dalam proses pembelajaran kategori ringan terdapat 12 responden yang mengalami stres sedang dan sisanya sebanyak 2 responden mengalami stres berat. responden mengalami stres ringan dan 3 responden dengan stres berat.

Tabel 1

Distribusi frekuensi karateristik responden

\begin{tabular}{|c|c|c|}
\hline Indikator & $\mathrm{f}$ & $\%$ \\
\hline \multicolumn{3}{|l|}{ Jenis Kelamin } \\
\hline Laki-laki & 27 & 11.7 \\
\hline Perempuan & 203 & 88.3 \\
\hline \multicolumn{3}{|l|}{ Jenjang Pendidikan } \\
\hline D3 Keperawatan & 131 & 57 \\
\hline S1 Keperawatan & 88 & 43 \\
\hline
\end{tabular}

Tabel 2

Hubungan pembelajaran daring dengan tingkat stres mahasiswa $(n=230)$

\begin{tabular}{|c|c|c|c|c|}
\hline \multirow{2}{*}{ Indikator } & \multicolumn{3}{|c|}{ Tingkat Stres } & \multirow[t]{2}{*}{$p$} \\
\hline & Ringan & Sedang & Berat & \\
\hline \multicolumn{5}{|l|}{ Kendala } \\
\hline \multicolumn{5}{|l|}{ Pembelajaran } \\
\hline Ringan & 0 & 12 & 2 & \\
\hline Sedang & 12 & 102 & 3 & 0,007 \\
\hline Berat & 3 & 95 & 1 & \\
\hline
\end{tabular}

\section{PEMBAHASAN}

Proses pembelajaran daring merupakan sistem pembelajaran jarak jauh yang dilaksanakan dengan tidak bertemu secara langsung, melainkan menggunakan platform yang dapat membantu proses belajar mengajar [12]. Ada beberapa media atau aplikasi yang dapat membantu kegiatan belajar mengajar secara daring, misalnya whatsapp, zoom, google met dan lain-lain.

Perubahan proses pembelajaran akibat dari mewabahnya virus Covid-19 ini menjadi beban tersendiri dan membutuhkan adaptasi serta usaha agar dapat berjalan dengan baik [8]. Perubahan ini ternyata menimbulkan berbagai dampak negatif pada mahasiswa seperti perasaan cemas, takut, jenuh, stres hingga depresi [13]. Perubahan ini menjadi stressor bagi mahasiswa karena mahasiswa dihadapakan pada suatu pergeseran kebiasaan yang terjadi secara singkat yaitu dari perkuliahan secara tatap muka langsung di kampus menjadi kuliah secara online dimana mahasiswa dituntut untuk beradaptasi terhadap perubahan tersebut [11]. Ketika seseorang melakukan aktivitas sehari-hari secara rutin maka akan terbentuk suatu pola kebiasaan, hal ini dapat mengurangi jumlah energi dan sumber daya yang digunakan, dan ketika kebiasaan itu berubah maka perubahan tersebut memaksa seseorang untuk meningkatkan penggunaan energi agar dapat beradaptasi, sehingga perubahan situasi yang tidak diinginkan ini menimbulkan stres psikologis pada seseorang [14].

Dari hasil penelitian diketahui bahwa sebagian besar mahasiswa pada penelitian ini mengalami cukup kendala dalam proses pembelajaran daring. Hasil penelitian menunjukkan bahwa terdapat hubungan yang bermakna antara pembelajaran daring dengan tingkat stres mahasiswa keperawatan. Beberapa riset terdahulu telah membuktikan bahwa pembelajaran daring pada masa pandemi memberikan dampak psikologis pada mahasiswa, seperti penelitian lain yang menjelaskan bahwa didapatkan sebagian besar mahasiswa mengalami stres sedang sebanyak 27 orang $(38,57 \%)$, stres berat sebanyak 20 orang $(28,57 \%)$, sedangkan sisanya sebanyak 23 orang mengalami stres ringan $(32,86 \%)[8]$. 
Selama proses pembelajaran daring mahasiswa merasakan tekanan yang cukup berat, hal ini dibuktikan dengan gambaran tingkat stres akademik pada mahasiswa selama kuliah daring yang mayoritas mengalami stres akademik pada kategori sedang sebanyak 80 orang $(39,2 \%)$, kategori tinggi sebanyak 55 orang $(27 \%)$, kategori rendah sebanyak 48 orang (21\%), kategori sangat tinggi sebanyak 14 orang $(5,4 \%)$ dan kategori sangat rendah sebanyak 11 orang $(5,4 \%)$ [15]. Riset lain juga menunjukkan ada hubungan yang bermakna antara frekuensi pelaksanaan pembelajaran jarak jauh dengan tingkat stres mahasiswa [5].

Perkuliahan daring sebagai bagian dari upaya pencegahan perkembangan dan penyebaran Covid-19 ternyata memberikan dampak psikologis kepada mahasiswa dimana dalam penelitian ini ditemukan hubungan antara kendala dalam pembelajaran daring dengan tingkat stres pada mahasiwa keperawatan. Kendalakendala seperti jaringan internet yang lemah, kuota internet terbatas, sulit berkonsentrasi dan memahmai materi, tugas perkuliahan yang banyak, kurang memahami media elektronik dan kendala lainya, menjadi pemicu stres bagi mahasiswa.

Stres yang tidak mampu diatasi akan mempengaruhi fisik, koognitif, emosi dan perilaku seseorang. Dimana dampak terbesar akibat stres adalah kondisi fisik seseorang diantaranya mengalami gangguan tidur, peningkatan denyut jantung, ketegangan otot, pusing, kelelahan dan kekurangan energi[16]. Mahasiswa yang mengalami stres secara kognitif akan sulit untuk memusatkan perhatian saat belajar, sulit mengingat materi, sulit memahami materi pelajaran, berpikir negatif pada dirinya sendiri dan lingkunganya. Dari segi emosi mahasiswa akan merasa cemas, sensitif, sedih, marah, frustasi. Selain itu dampak perilaku yang muncul akibat stres yaitu merusak, menghindar, membantah, menghina, menunda penyelesaian tugas kuliah, rasa malas kuliah dan terlibat dalam kegiatan mencari kesenangan yang belebihan dan beresiko [17]. Sejalan dengan hasil penelitian mengenai dampak negatif pembelajaran daring pada 110 mahasiswa semester awal dari berbagai perguruan tinggi di Indonesia, dimana hasil penelitian tersebut menunjukkan mahasiswa merasa proses pembelajaran daring kurang efektif, merasa lebih lelah, kesehatan mudah menurun, sering mengalami nyeri punggung, sakit kepala, dan sakit mata[13].

Stres yang berlangsung terus-menerus dan terjadi dalam jangka waktu yang lama dapat mengakibatkan peningkatan detak jantung yang konsisten dan berkelanjutan, serta peningkatan kadar hormon stres dan tekanan darah, hal ini dapat berdampak buruk pada tubuh yaitu meningkatkan risiko hipertensi, serangan jantung, atau stroke[18]. Stres psikologis juga dapat mempengaruhi sistem imun, dimana ketika stres, terjadi pelepasan hormon glukokortikoid dan katekolamin yang mengakibatkan penekanan sistem imun[19]. Hal ini menyebabkan seseorang mudah terserang penyakit bahkan dapat menyebabkan pertumbuhan sel ganas atau cancer [20].

\section{SIMPULAN}

Terdapat hubungan pembelajaran daring di masa pandemi covid-19 dengan tingkat stres pada mahasiswa keperawatan. Stres yang dirasakan oleh mahasiswa terkait dengan kendala-kendala dalam pelaksanaan pembelajaran daring seperti proses pembelajaran daring yang mulai membosankan, tidak dapat mengikuti pembelajaran daring karena kuota internet terbatas, tidak dapat mengaplikasikan pembelajaran praktek laboratorium karena ketidaktersedian alat, sulit berkonsentrasi dan memahami materi pembelajaran, tugas perkuliahan yang banyak, dan kurang pahan dalam menggunakan media elektronik. 


\section{UCAPAN TERIMAKASIH}

Penulis mengucapkan terimakasih kepada Ketua Program Studi Ilmu Keperawatan dan DIII Keperawatan atas izin dan dukungan dala proses penelitian ini dan terimakasih pula kepada seluruh mahasiswa keperawatan yang bersedia menjadi responden dalam penelitian ini.

\section{REFERENSI}

[1] WHO. Pesan dan Kegiatan Utama Pencegahan dan Pengendalian COVID-19 di Sekolah. Unicef 2020.

[2] Ph L, Fatkhul Mubin M, Basthomi Y. "Tugas Pembelajaran" Penyebab Stres Mahasiswa Selama Pandemi Covid-19. 2020. https://doi.org/10.32584/JIKJ.V3I2.590.

[3] Watnaya A kusnayat, Muiz M hifzul, Nani Sumarni, Mansyur A salim, Zaqiah Q yulianti. Pengaruh Teknologi Pembelajaran Kuliah Oline di Era Covid-19 Dan Dampaknya Terhadap Mental Mahasiswa. EduTeach J Edukasi Dan Teknol Pembelajaran 2020. https://doi.org/10.37859/eduteach.v1i2.1987.

[4] Hasanah U, Keperawatan dan Profesi Ners I, Tinggi Ilmu Kesehatan Kendal S, Laut J, Kendal A. Gambaran Psikologis Mahasiswa Dalam Proses Pembelajaran Selama Pandemi Covid19. J Keperawatan Jiwa 2020. https://doi.org/10.26714/JKJ.8.3.2020.299306.

[5] Putri RM, Oktaviani AD, Utami ASF, ... Hubungan Pembelajaran Jarak Jauh dan Gangguan Somatoform dengan Tingkat Stres Mahasiswa UIN Syarif Hidayatullah Jakarta. ... Promosi Kesehat 2020.

[6] Hasanah A, Sri Lestari A, Rahman AY, Danil YI. Analisis Aktivitas Belajar Daring Mahasiswa Pada Pandemi COVID-19. Karya Tulis Ilm Masa Work From Home Covid-19 UIN Sunan Gunung Djati Bandung Tahun 20202020.

[7] Szpunar KK, Moulton ST, Schacter DL. Mind wandering and education: From the classroom to online learning. Front Psychol 2013. https://doi.org/10.3389/fpsyg.2013.00495.

[8] Sari MK. Tingkat Stres Mahasiswa S1 Keperawatan Tingkat Satu Dalam Menghadapi Wabah Covid 19 Dan Perkuliahan Daring Di
Stikes Karya Husada Kediri. J Ilm Pamenang 2020.

[9] Son C, Hegde S, Smith A, Wang X, Sasangohar F. Effects of COVID-19 on College Students' Mental Health in the United States: Interview Survey Study. J Med Internet Res 2020. https://doi.org/10.2196/21279.

[10] Santrock. Life-Span Development: Perkembangan Masa Hidup. 2003. https://doi.org/10.1109/ciced.2018.8592188.

[11] Lumban Gaol NT. Teori Stres: Stimulus, Respons, dan Transaksional. Bul Psikol 2016. https://doi.org/10.22146/bpsi.11224.

[12] Sofyana L, Rozaq A. Pembelajaran Daring Kombinasi Berbasis Whatsapp Pada Kelas Karyawan Prodi Teknik Informatika Universitas PGRI Madiun. J Nas Pendidik Tek Inform 2019. https://doi.org/10.23887/janapati.v8i1.17204

[13] Fitria PA, Saputra DY. Dampak Pembelajaran Daring Terhadap Kesehatan Mental Mahasiswa Semester Awal. J Ris Kesehat Nas 2020. https://doi.org/10.37294/jrkn.v4i2.250.

[14] Fuad FT. Hubungan antara Penyesuaian Diri di Perguruan Tinggi dan Stres Psikologis pada Mahasiswa Tahun Pertama Fakultas Psikologi Universitas Indonesia. Univ Indones 2013.

[15] Lubis H, Ramadhani A, Rasyid M. Stres Akademik Mahasiswa dalam Melaksanakan Kuliah Daring Selama Masa Pandemi Covid 19. Psikostudia J Psikol 2021. https://doi.org/10.30872/psikostudia.v10i1.5 454.

[16] Bressert, Steve. P. The Impact Of Stress. Psych Cent 2016.

[17] Aryani F. Stres Belajar : Suatu Pendekatan dan Intervensi Konseling. Makasar: Edukasi Mitra Grafika; 2016.

[18] Shaw W, Labott-Smith S, Burg M, Hostinar C, Alen N, van Tilburg M AL, et al. Stress effects on the body. Am Psychol Assoc 2018.

[19] Wardhana Bagian M, Ilmu Kesehatan Kulit dan Kelamin S. Psikoneuroimunologi di Bidang Dermatologi. MDVI 2011.

[20] Yaribeygi H, Panahi Y, Sahraei H, Johnston TP, Sahebkar A. The impact of stress on body function: A review. EXCLI J 2017. https://doi.org/10.17179/excli2017-480. 